\title{
Evaluation of Bacteriological Quality of Packed Ice Creams Sold In Retail Stores in Tripoli City, Libya
}

Mohamed R. Alsagher*, Izdehar M. Alahdab, Sahar N. Alkhwildi, Najat Elmaghrhi, Ayda Ghalboon and Raja M. Moman

Department of Microbiology and Immunology, Faculty of Pharmacy, University of Tripoli, Tripoli / Libya

DOI: $10.36347 /$ sajp.2021.v10i01.004

| Received: 29.12.2020 | Accepted: 14.01.2021 | Published: 27.01.2021

*Corresponding author: Prof. Mohamed R. Alsagher

Abstract

Original Research Article

Ice cream is considered as one of the most favorable media for growing of bacterial species and as potential source of food poisoning. The main objective of the present study was to determine the bacterial loads of ice cream. A total of thirty samples of fourteen packed ice cream brands were collected from different retail stores in Tripoli city of Libya. Thereafter, their bacteriological quality were assessed and studied comparatively. Total Bacterial viable count (TBVC), total coliform count (TCC) were determined in plate count agar (PCA). Mannitol salt agar (MSA) and Eosin methylene blue (EMB) agar, Salmonella-Shigella agar and Listeria agar were used for Staphylococcus aureus, E. coli, Salmonella spp. and Listeria spp. count respectively. The results revealed that all samples had TBVC of cfu/g ranging from $1 \times 10^{4}$ to $8 \times 10^{4}$, in which $7(23.3 \%)$ of the ice cream samples fell within the acceptable limit and met the standard plate count according to the Libyan Standard for Ice Cream (LSIC, 1997). By contrast, 7 samples (23.3\%) showed zero TBVC. Moreover, 16 sample $(53.3 \%)$ showed contamination with bacteria in a numbers too numerous to be counted (TNTC). However, on the basis of total coliform count, 20 samples (66.7\%) showed high level of contamination. In conclusion, the majority of ice creams have been contaminated with pathogens in particularly Escherichia coli. Hence, it is recommend that a greater attention is needed to apply strict microbiological quality control to ensure the safety of final products of ice creams by improving the quality of production technology and sanitation strategies.

Keywords: Bacterial contamination, packaged ice cream, coliform count Salmonella, E. coli.

Copyright ( 12021 The Author(s): This is an open-access article distributed under the terms of the Creative Commons Attribution 4.0 International License (CC BY-NC 4.0) which permits unrestricted use, distribution, and reproduction in any medium for non-commercial use provided the original author and source are credited.

\section{INTRODUCTION}

Ice cream is one of nutritionally enriched dairy product and commonly consumed as frozen milk and an excellent source of food energy. In addition of milk, ice cream contains a variety of ingredients such as, cream, fat, sugar, emulsifier, stabilizer, colors, an optional enrichment flavors [1], calcium, phosphorous and minerals [2]. As a milk based product with high nutrients value, almost neutral $\mathrm{pH}$ value $(\mathrm{pH}$ 6-7) ice cream is considered as a good media for microbial growth leading to microbial contamination of the product. Microbial contamination can occur at various stages of manufacturing and during addition of ingredients. Moreover, operators carrying certain diseases are considered as a major source for contaminating the ice cream with potential pathogens especially during handling of the product with contaminated hands. Additionally, factors such as tools, equipment, water, workers, environment, packaging materials, transportation and distribution may contribute to the transmission of microbes into ice cream [3]. Moreover, improper maintenance of machines used for production of soft ice cream can play an important role in microbial contamination especially due to biofilm formation [4-7]. High quality ice cream is associated with the stages of production $[8,9]$ in which several factors including cleaning and disinfection, hygiene of storage area, hygienic design and personnel training have to be implemented. High bacteria counts and potential public health hazard may occur due failure to adhere to these factors [9]. Hence, strict microbiological quality control must be applied on ice cream manufacturing in order to builds quality into the product assurance the highest possible of error free from any of the pathogens [2].

\section{OBJECTIVE}

The aim of this study was to evaluate the bacteriological quality of selected ice cream marketed 
in Tripoli city and to assess the potential of this frozen product to pose risk to public health.

\section{MATERIALS AND METHODS Sample collection}

In this study, 30 ice cream samples were collected randomly from different retail stores in Tripoli city of Libya. The samples comprised of fourteen packed/industrial ice cream brands; three samples each was collected for each brand over a period of three months and were assessed for their bacteriological quality.

\section{Total bacterial viable count (TBVC)}

Ten grams of ice-cream sample was weighed and diluted in $90 \mathrm{ml}$ of buffer peptone water. One $\mathrm{ml}$ of buffered solution was serially diluted in normal saline up to dilutions of $\left(10^{-3}\right)$ and $\left(10^{-4}\right) .100 \mu$ of each dilution was plated out in triplicate onto plate count agar media and incubated at $37^{\circ} \mathrm{C}$ for $48 \mathrm{~h}$; typical growing colonies were then counted and identified.

\section{Isolation and identification of pathogenic bacteria}

TBVC and total coliform count were determined in plate count agar (PCA). Mannitol salt agar (MSA) and Eosin methylene blue (EMB) agar were used for Staphylococcus aureus and E. coli count respectively. For the detection of Salmonella and Listeria, enrichment was done using Selenite F broth and Listeria Enrichment Broth and then plated on Salmonella-Shigella agar and Listeria agar respectively. Typical colonies were selected and their identity was confirmed by standard biochemical reactions [10]. All types of culture media are manufactured by (OXOIDUnipath Ltd. Basings STOKE, Hampshire, U.K.).

\section{RESULTS \& DISCUSSION}

The bacteriological quality of ice cream consumed by public in Tripoli city was investigated in this study and four bacteria were isolated; Escherichia coli, Staphylococcus aureus, Salmonella spp., and Listeria spp. All the 30 samples of ice cream examined showed positive for one or two types of bacteria, the table 2.1 presents the distribution of all types of bacteria among different types of ice cream. Viable microbial population obtained by standard plate count reflects the microbiological quality of product examined. The results in table 2.1 show that all samples had TVBC of $\mathrm{cfu} / \mathrm{g}$ ranging from $1 \times 10^{4}$ to $8 \times 10^{4}$, in which $7(23.3 \%)$ of the ice cream samples fell within the acceptable limit and met the standard plate count according to LSIC which are $\leq 3 \times 10^{4}$ and $\leq 10 \mathrm{cfu} / \mathrm{ml}$ respectively [11]. By contrast, 7 samples (23.3\%) showed zero TVBC. Moreover, 16 sample $(53.3 \%)$ showed contamination with bacteria in numbers too numerous to be counted (TNTC). These is out of the limit set by the Libyan Standard for Ice Cream (LSIC, 1997) and Bureau of Food and Drugs (BFAD), which are $\leq 3 \times 10^{4}$ and $2.5 \times 10^{5} \mathrm{cfu} / \mathrm{ml}$ respectively. Higher percentage of bacterial contamination $(80 \%)$, TVBC ranged between
$3 \times 10^{1}$ and $5 \times 10^{8} \mathrm{cfu} / \mathrm{ml}$ and the MPN values of coliforms between 0.0 and $11 / \mathrm{ml}$ found in ice cream samples collected from different manufactures were reported in the only single study carried out by ElSharef, et al., [11] in Tripoli city. However, on the basis of total coliform count by MPN technique (table 2.2), bacterial contamination was detected in all samples, in which 20 samples (66.7\%) showed high level of contamination $(>2.400 \mathrm{MPN} / \mathrm{g})$. This result is beyond limits set by LSIC, and still also beyond the limits set by bureau of Food and Drugs (BFAD), which is $2.5 \times 10^{5}$ $\mathrm{cfu} / \mathrm{g}$ and $100 \mathrm{MPN}$ coliforms [12]. Bacterial load not more than $10^{5}$ bacteria in ice cream samples reflect good hygiene [23], however values above $10^{5}$ are unacceptable [13]. In this study, the highest count $\left(8 \times 10^{4}\right)$ and the lowest count $\left(1 \times 10^{4}\right)$ were recorded for Pepeto-chocolate ice cream (sample number 28) and Naseem (type bundok) ice cream (sample number 8) respectively. Similar results for other branded ice creams were recorded by Okojoh [14], Moshood and Tengku [15] and Edward et al., [16]. High value of standard plate count $\left(10^{6} \mathrm{cfu} / \mathrm{g}\right)$ has also been reported by [17]. The difference in standard plate count from sample to sample of tested ice creams presented in this investigation may be attributed to the different sanitary practices adopted in different ice cream plants and outlets during manufacture, packaging, storage and distribution of the product and also due to addition of optional ingredients after pasteurization of the mix (color, essence, fruit, nut, sauce, etc.). All of the samples tested in this study were negative for Staph. aureus and Listeria spp., while E. coli was detected in 20 ice cream samples $(66.67 \%)$ and Salmonella spp. in 12 ice cream samples $(40 \%)$. In the testing for Salmonella, a study conducted by Silveira et al., [18], and Hoffmann et al., [19] after investigating the hygienic-sanitary quality of ice cream resulted positive for Salmonella spp. in $75 \%$ of the samples revealing higher value than obtained in this study, also Emad Abou-El Khair, et al., [20] represented that, the highest level of contamination (56\%) was occurred with coliform E. coli. According to (TFC, 2011), the presence of Salmonella spp. and Listeria monocytogenes in $25 \mathrm{~g}$ of ice cream is not acceptable. In this study $10 \mathrm{~g}$ was used in which Salmonella spp. were detected in $40 \%$ of ice cream samples. The present work had a result different to the study conducted by Emad Abou-El Khair, et al., [20] and Tolga Kahraman and Kolanciyan on 2016 [22] in which all of tested samples were found negative for Salmonella spp., while only small percentage $(0.67 \%)$ of samples was found contaminated with Listeria monocytogenes.

The assessment of TBVC has clearly provided information that the ice cream sample of Extreme (sample number 27) was of the superior quality, followed by Yasmina; type. Ella-Ya-Ella (sample number 16) and then Extreme-gold (sample number 27) because the counts were less than the recommended 
Mohamed R. Alsagher et al., Sch Acad J Pharm, Jan, 2021; 10(1): 19-23

microbiological standard of US Food and Drug administration [21].

\section{CONCLUSION}

In the general context of this study, it can be concluded that, the majority of selected ice cream samples have an unacceptable level of bacterial contamination and did not present satisfactory microbiological quality giving an indication of improper sanitary condition in Tripoli, and may play a significant role in the transmission of potentially vital bacteria causing different diseases, and might pose risks to the consumers' health. Therefore, it's recommend that a greater attention is needed to apply strict microbiological quality control to ensure that the ice cream product received by the consumer will be pure, healthful and of the quality claimed. Accordingly, implementation of effected legislation and proper public educational programs towards maintaining strict hygienic control regarding; production, handling, processing, distribution and storage of ice cream are of great importance in order to protect consumers against health hazard might be raised from contaminated products. Thus, controlling the microbial quality of ice creams is a prime responsibility of the government health authorities to take intensive investigation towards this issue to improve the hygienic quality of ice cream in all steps, post pasteurization and at retail level. The ice creams tested in the current study were commonly contaminated with some strains of pathogenic bacteria. From the four common bacterial strains (Escherichia coli, Staphylococcus aureus, Salmonella spp., and Listeria spp.) that expected to contaminate the collected samples of ice cream, only two strains of bacterial species were highlighted. The active participation of these two species in descending order of percentage as E. coli $(66.67 \%)$ and Salmonella spp. (40\%) and no growth colonies were observed for Staphylococcus aureus and Listeria spp. The isolation of E. coli, and Salmonella spp. suggests that ice cream could be a source of infection to humans particularly for children and vulnerable elderly people by members of the Enterobacteriaceae [16]. Finally, it is strongly recommended that more studies on this subject would be required on other Libyan cities to report with certainty the percentage and types of pathogenic bacteria causing cross infection among Libyan people due to consumption of ice creams.

\section{ACKNOWLEDGEMENT}

We gratefully acknowledge the final year pharmacy project students who participated in this study and the Technicians in Department of Microbiology and Immunology at Faculty of Pharmacy, University of Tripoli for their valuable help in aspects of microbiological techniques.

Table-2.1: Bacteriological quality of ice cream marketed in Tripoli city, Libya

\begin{tabular}{|c|c|c|c|c|c|c|c|c|}
\hline \multirow[b]{2}{*}{ № } & \multicolumn{2}{|c|}{ Sample } & \multirow{2}{*}{$\begin{array}{l}\text { Coliforms } \\
\text { (MPN/g) }\end{array}$} & \multirow{2}{*}{$\begin{array}{l}\text { TBVC } \\
\left(\mathrm{cfu} / \mathrm{gx} 10^{4}\right)\end{array}$} & \multicolumn{4}{|c|}{ Isolated bacteria } \\
\hline & Name & Type & & & E. coli & $\begin{array}{l}\text { Salmonella } \\
\text { spp. }\end{array}$ & $\begin{array}{l}\text { Staph. } \\
\text { aureus }\end{array}$ & Listeria spp. \\
\hline 1 & \multirow{11}{*}{ 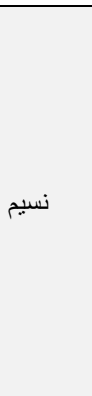 } & طريفه & $>2.400$ & 0 & + & + & - & - \\
\hline 2 & & لبنى & 460 & 9 & + & + & - & - \\
\hline 3 & & سندباد & $>2.400$ & 0 & + & - & - & - \\
\hline 4 & & عملاق & $>2.400$ & 0 & + & - & - & - \\
\hline 5 & & متاز & $>2.400$ & TNTC & + & - & - & - \\
\hline 6 & & رامي & $>2.400$ & TNTC & + & - & - & - \\
\hline 7 & & نافع & 43 & TNTC & + & - & - & - \\
\hline 8 & & بندق & 9 & 1 & - & + & - & - \\
\hline 9 & & فرحان - شوكو لاتة & 28 & 0 & - & + & - & - \\
\hline 10 & & فرحان - فراولة & $>2.400$ & 0 & - & + & - & - \\
\hline 11 & & متاز & $>2.400$ & TNTC & + & - & - & - \\
\hline 12 & \multirow{4}{*}{ شهرزاد } & فستق & 43 & TNTC & - & - & - & - \\
\hline 13 & & موجه & $>2.400$ & TNTC & - & + & - & - \\
\hline 14 & & فانيليا & $>2.400$ & 9 & - & - & - & - \\
\hline 15 & & البرج & $>2.400$ & TNTC & + & + & - & - \\
\hline 16 & \multirow{3}{*}{ ياسمينه } & ياعيلة عيله & 7 & 0 & - & - & - & - \\
\hline 17 & & قنين & 240 & TNTC & + & - & - & - \\
\hline 18 & & بحبوح & $>2.400$ & TNTC & + & - & - & - \\
\hline 19 & \multirow{2}{*}{ ثالجه } & Turbo & $>2.400$ & 3 & + & + & - & - \\
\hline 20 & & Super Cano & $>2.400$ & TNTC & + & - & - & - \\
\hline 21 & \multicolumn{2}{|c|}{ بطريق- كر انش } & $>2.400$ & 20 & - & + & - & - \\
\hline 22 & \multicolumn{2}{|c|}{ هناء بنكهة الشكو لاته } & $>2.400$ & TNTC & + & - & - & - \\
\hline 23 & \multicolumn{2}{|c|}{ فيلادلفيا } & $>2.400$ & TNTC & + & + & - & - \\
\hline 24 & \multicolumn{2}{|l|}{ دولفي } & $>2.400$ & 37 & + & + & - & - \\
\hline 25 & \multicolumn{2}{|c|}{ سامبا_ المذاق } & $>2.400$ & TNTC & + & - & - & - \\
\hline 26 & \multicolumn{2}{|c|}{ Extreme } & $<3$ & 0 & - & - & - & - \\
\hline 27 & \multicolumn{2}{|c|}{ Extreme-gold } & 28 & TNTC & - & - & - & - \\
\hline 28 & \multicolumn{2}{|c|}{ Pepeto-chocolate } & 480 & 80 & + & - & - & - \\
\hline 29 & \multicolumn{2}{|c|}{ Pepeto-strawberry } & $>2.400$ & TNTC & + & - & - & - \\
\hline 30 & \multicolumn{2}{|c|}{ Twister } & $>2.400$ & TNTC & + & + & - & - \\
\hline
\end{tabular}

TNTC, too numerous to count (i.e. bacteria in a numbers over $300 \mathrm{cfu}$ ) 
Mohamed R. Alsagher et al., Sch Acad J Pharm, Jan, 2021; 10(1): 19-23

Table-2.2: Most Probable Number (MPN) per $1 \mathrm{~g}$ of sample and $95 \%$ confidence limit

\begin{tabular}{|c|c|c|c|c|c|c|c|c|}
\hline \multirow[t]{2}{*}{ № } & \multicolumn{2}{|c|}{ Sample } & \multicolumn{3}{|c|}{$\begin{array}{l}\text { Number of positive tubes } \\
\text { in three sets of tubes with } \\
\text { three different dilutions }\end{array}$} & \multirow[t]{2}{*}{ MPN/g } & \multicolumn{2}{|c|}{ MPN Limit } \\
\hline & Name & Type & 0.1 & 0.01 & 0.001 & & Lower & Upper \\
\hline 1 & \multirow{11}{*}{ نسيم } & طريفه & 3 & 3 & 3 & $>2.400$ & & \\
\hline 2 & & لبنى & 3 & 3 & 1 & 460 & 71 & 2.400 \\
\hline 3 & & سندباد & 3 & 3 & 3 & $>2.400$ & & \\
\hline 4 & & عملاق & 3 & 3 & 3 & $>2.400$ & & \\
\hline 5 & & مثتاز & 3 & 3 & 3 & $>2.400$ & & \\
\hline 6 & & نافع & 3 & 1 & 0 & 43 & 7 & 210 \\
\hline 7 & & رامي & 3 & 3 & 3 & $>2.400$ & & \\
\hline 8 & & بندق & 2 & 0 & 0 & 9 & 1 & 36 \\
\hline 9 & & فرحان - شوكو لاتة & 3 & 0 & 0 & 28 & 4 & 120 \\
\hline 10 & & فرحان - فراولة & 3 & 3 & 3 & $>2.400$ & & \\
\hline 11 & & ممتاز & 3 & 3 & 3 & $>2.400$ & & \\
\hline 12 & \multirow{4}{*}{ شهرزاد } & فستق & 3 & 1 & 0 & 43 & 7 & 210 \\
\hline 13 & & موجه & 3 & 3 & 3 & $>2.400$ & & \\
\hline 14 & & فانيليا & 3 & 3 & 3 & $>2.400$ & & \\
\hline 15 & & البرج & 3 & 3 & 3 & $>2.400$ & & \\
\hline 16 & \multirow{3}{*}{ ياسمينه } & عيله & 1 & 1 & 0 & 7 & 1 & 21 \\
\hline 17 & & فينين & 3 & 3 & 0 & 240 & 36 & 1.300 \\
\hline 18 & & بحبوح & 3 & 3 & 3 & $>2.400$ & & \\
\hline 19 & \multirow{2}{*}{ ثالجه } & Turbo & 3 & 3 & 3 & $>2.400$ & & \\
\hline 20 & & Super Cano & 3 & 3 & 3 & $>2.400$ & & \\
\hline 21 & \multicolumn{2}{|c|}{ بطريق- كر انش } & 3 & 3 & 3 & $>2.400$ & & \\
\hline 22 & \multicolumn{2}{|c|}{ هناء بنكهة الثكو لاته } & 3 & 3 & 3 & $>2.400$ & & \\
\hline 23 & \multicolumn{2}{|c|}{ فيلادلفيا } & 3 & 3 & 3 & $>2.400$ & & \\
\hline 24 & \multicolumn{2}{|l|}{ دولفي } & 3 & 3 & 3 & $>2.400$ & & \\
\hline 25 & \multicolumn{2}{|c|}{ سامباـ المذاق } & 3 & 3 & 3 & $>2.400$ & & \\
\hline 26 & \multicolumn{2}{|c|}{ Extreme } & 0 & 0 & 0 & $<3$ & 0.5 & 9 \\
\hline 27 & \multicolumn{2}{|c|}{ Extreme-gold } & 3 & 3 & 0 & 240 & 36 & 1.300 \\
\hline 28 & \multicolumn{2}{|c|}{ Pepeto-chocolate } & 3 & 3 & 3 & $>2.400$ & & \\
\hline 29 & \multicolumn{2}{|c|}{ Pepeto-strawberry } & 3 & 1 & 1 & 75 & 14 & 230 \\
\hline 30 & \multicolumn{2}{|c|}{ Twister } & 3 & 3 & 3 & $>2.400$ & & \\
\hline
\end{tabular}

\section{REFRENCES}

1. Or F. A research on the evaluation of microbiological quality of plain ice cream which is produced in accordance with Kahramanmaras style produced in Kahramanmaras. Master Thesis. Cukurova University, Institute of Natural and Applied Science Department of Food Engineering, Adana; 2009.

2. Barman AK, Roy PK, Ray S, Kumar R, Rani B, Singh BK. Evaluation of microbiological quality of Ice-cream available in Kolkata and its Suburbs. The Pharma Innovation. 2017 Aug 1;6(8, Part F):377.

3. Elliott RP, Clark DS, Lewis KH, Lundbeck H, Olson Jr JC. Microorganisms in foods 1: Their significance and methods of enumeration-2.

4. Hennessy TW, Hedberg CW, Slutsker L, White KE, Besser-Wiek JM, Moen ME, Feldman J, Coleman WW, Edmonson LM, MacDonald KL, Osterholm MT. A national outbreak of Salmonella enteritidis infections from ice cream. New England Journal of Medicine. 1996 May 16;334(20):1281-6.
5. Dempsey PG, McGorry RR, Cotnam J, Braun TW. Ergonomics investigation of retail ice cream operations. Applied ergonomics. 2000 Apr 3;31(2):121-30.

6. Kleer J, Hildebrandt G. Microbial contamination of frozen foods. Archiv für Lebensmittelhygiene. 2000;51(2):42-5.

7. Nelapati S, Krishnaiah N, Kiranmayi B. Studies on physico-chemical and microbiological quality of ice-creams sold in and around Greater Hyderabad Municipal Corporation. Journal of Veterinary Public Health. 2009;7(2):121-4.

8. Little CL, De Louvois J. The microbiological quality of soft ice-cream from fixed premises and mobile vendors. International Journal of Environmental Health Research. 1999 Sep $1 ; 9(3): 223-32$.

9. Roberts TA, Pitt IJ, Farkas J and Grau FH. Milk and dairy products. In: Microorganisms in Foods 6. International Commission on Microbiological Specifications for Foods. Blackie Academic and Professional, London. 1998; 521-528, 559-563. 
Mohamed R. Alsagher et al., Sch Acad J Pharm, Jan, 2021; 10(1): 19-23

10. Ambily R, Beena AK. Bacteriological quality of icecream marketed in Thrissur town, Kerala, India. Veterinary World. 2012 Dec 1;5(12):738.

11. El-Sharef N, Ghenghesh KS, Abognah YS, Gnan SO, Rahouma A. Bacteriological quality of ice cream in Tripoli-Libya. Food Control. 2006 Aug 1;17(8):637-41.

12. Orallo GO, Pangan AH, Cabrera EC. Microbial Analysis of Ice Cream Produced by Big-Scale and Small-Scale. Manufacturers in Metro Manila. Phil J Microbiol Infect Dis. 1999;28(3):99-101.

13. Frazier WC and Westhoff DC. Food Microbiology. 5th ed. (Ed: Vanitha N. M.) McGraw-Hill Education (India) Private Limited, 361and 484; 2014.

14. Ojokoh AO. Microbiological examination of ice cream sold in Akure. Pakistan Journal of Nutrition. 2006;5(6):536-8.

15. Yusuf MA, Abdul T, Hamid TA, Yusuf MM. Assessment of the bacteriological quality of ice cream offered for public consumption in Bauchi, Nigeria. J. Pharm. 2013;3:25-30.

16. Edward KC, Owuamalam PO, Onyekachi OV, Nnochiri OA, Akumah CN. Microbial quality assessment of ice cream sold in umuahia, SouthEastern Nigeria: a comparative study. Journal of Biology, Agriculture and Healthcare. 2017;7(16):40-8.
17. Guha AK, Das HNR, Dewan ML. Microorganisms in ice cream and their public health significance. J Food Sci. and Tech., India. 1979; 16(4):61-164.

18. Silveira H, Sampaio Neta N, Pinto R, Rodrigues M, Costa J. Avaliação da qualidade físico-química e microbiológica de sorvetes do tipo tapioca. Rev. Ciência Agronômica 2009; 40(1):60-5.

19. Hoffmann FL, Penna ALB, Coelho AR. Qualidade higiênico-sanitária de sorvetes comercializados na cidade de São José do Rio Preto-SP-Brasil. Rev Hig Alimentar. 2000; 76(11):62-68.

20. Emad Abou-El Khair, Abd Al- Raziq Salama, Hamdan Radwan, Abdelrahman Khalafallah, Hashem Arafa. Bacteriological Quality of Packaged Ice-Cream in Gaza City, Palestine. Journal of Food and Nutrition Sciences. 2014; 2(3): 68-73.

21. US Food and Drug Administration. Bacteriological Analytical Manual. Association of Official Analytical Chemists, Arlington, $6^{\text {th }}$ edition. 1984; 702-718.

22. Tolga Kahraman, Ari Manuk Kolanciyan. Microbiological Quality of Ice Cream Consumed in Istanbul. Veterinaria. 2016; 65(3); 111-115.

23. Frazier WC, Westhoff DC. Food Microbiology 3rd Edition McGraw Hill Book company. New York. 1978;540.

24. Turkish Food Codex (TFC). Republic of Turkey Ministry of Food, Agriculture and Livestock. 2011; No: 28157. 